\title{
Peningkatan Pengetahuan Ibu Mengenai Gizi Seimbang Dalam Pemenuhan Gizi Keluarga
}

\author{
Rifatul Masrikhiyah \\ Program Studi Ilmu Gizi, Fakultas Ilmu Kesehatan, Universitas Muhadi Setiabudi \\ *e-mail: rifatul.masrikhiyah@gmail.com
}

\begin{abstract}
The prevelency of children's nutritional problems is still high, not only the lack of nutritional problems resulting in children stunting and uderweight; And more nutrients that cause obesity and diabetes. One of the causes of nutritional problems is ignorance about healthy menu and lack of awareness of Kadarzi. This activity aims to improve the knowledge of mothers on balanced nutrition in the fulfillment of family nutrition. PkM is held in Sengon village RT/RW 001/003 kedependants District Brebes in July 2019. The subjects that followed the activities amounted to 25 mothers - housewives. This activity consists of 3 stages including: preparation stage, implementation stage and interview stage. Data is obtained from pre test results and post tests and discussions. Results of this activity is an increase in the knowledge of the mother about balanced nutrition in the fulfillment of family nutrition, there is an increase from $12 \%$ to $76 \%$.
\end{abstract}

Keywords: balanced nutrition, family nutrition, housewife

\begin{abstract}
Abstrak
Prevelensi masalah gizi anak masih tinggi, tidak hanya masalah gizi kurang yang mengakibatkan anak anak stunting dan uderweight; dan gizi lebih yang menyebabkan obesitas dan diabetes. Salah satu penyebab permasalahan gizi yaitu ketidaktahuan mengenai menu sehat dan kurangnya kesadaran akan kadarzi (Keluarga sadar gizi). Kegiatan ini bertujuan untuk meningkatkan pengetahuan ibu mengenai gizi seimbang dalam pemenuhan gizi keluarga. PkM dilaksanakan di Desa Sengon RT/RW 001/003 Kecamatan Ketanggungan Kabupeten Brebes pada bulan juli 2019. Subjek yang mengikuti kegiatan berjumlah 25 ibu ibu rumah tangga. Kegiatan ini terdiri dari 3 tahap meliputi: tahap persiapan, tahap pelaksanaan dan tahap wawancara. Data diperoleh dari hasil pre test dan post tes dan diskusi. Hasil kegiatan ini yaitu terdapat peningkatan pengetahuan ibu mengenai gizi seimbang dalam pemenuhan gizi keluarga, terjadi peningkatan dari $12 \%$ menjadi $76 \%$.
\end{abstract}

Kata kunci: Gizi seimbang, Gizi keluarga, Ibu rumah tangga

\section{PENDAHULUAN}

Pada era globalisai saat ini, orang terbiasa melakukan apapun serba praktis begitu pula makanan yang dikonsumsi. Mereka lebih menyukai makanan yang cepat saji seperti kentang goreng, pizza, burger, dan lain sebagainya. Makanan cepat saji ini mengandung kalori yang tinggi dan hanya memiliki sedikit kandungan gizi yang diperlukan tubuh. Makanan yang bergizi seimbang sebenarnya tidaklah selalu mahal, kita bisa menggunakan atau mengganti bahan pangan yang lebih murah dan mudah didapat seperti daging bisa digantikan dengan ikan sebagai sumber protein, Suparmi (2019) memodifikasi nugget ubi kayu dengan fortifikasi daging ikan sebagai sumber protein. Bila terlalu sering mengkonsumsi makanan cepat saji, maka akan berisiko mengalami penyakit seperti obesitas, diabetes tipe 2, gangguan pencernaan dan pernapasan, kerusakan gigi, dan lainnya. Menurut Adityanti, dkk (2015) Remaja yang mengkonsumsi fast food dengan frekuensi sering, berisiko lebih terhadap terjadinya obesitas.

Indonesia menghadapi masalah gizi ganda saat ini yaitu masalah gizi kurang yang mengakibatkan anak anak stunting dan uderweight; dan gizi lebih yang menyebabkan obesitas dan diabetes. Data Riset Kesehatan Dasar (Riskesdas) tahun 2018, mengenai proporsi gizi kurang dan gemuk pada balita mencapai $11,2 \%$ dan $8 \%$. Salah satu penyebab permasalahan gizi yaitu ketidaktahuan mengenai menu sehat dan kurangnya kesadaran akan kadarzi (Keluarga sadar gizi). Menu sehat adalah yang mengandung zat gizi seimbang sesuai dengan kebutuhan masing masing anggota keluarga diterima dan disukai mempertahankan status gizi optimal. 
Studi yang dilakukan di ungaran mengenai perilaku ibu buruh pabrik tentang Kadarzi dengan status gizi anak balita menunjukkan bahwa terdapat hubungan antara perilaku Kadarzi dengan status gizi anak balita (Oktaviana, 2012). Perilaku kadarzi pada orang tua berhubungan dengan pengetahuan dan pendidikan gizi orang tua. Kurangnya pengetahuan orang tua terutama ibu dapat menyebabkan penurunan perilaku kadarzi yang berakibat pada masalah gizi keluarga. Ibu memiliki peranan penting dalam menyediakan makana sehat bagi keluarganya, karena ibu merupakan kunci keluarga sadar gizi. Pendidikan gizi bagi orang tua sangat diperlukan untuk meningkatkan pengetahuan gizi dan mengurangi masalah gizi pada keluarga. Penelitian yang dilakukan oleh Irnani (2017) mengenai Pendidikan gizi dengan tema "Pengenalan Gizi Seimbang untuk Hidup Sehat dan Berprestasi" dihubungkan dengan pengetahuan gizi dan status gizi pada anak sekolah dasar menunjukkan bahwa Pendidikan gizi meningkatkan pengetahuan gizi dari kategori kurang menjadi cukup.

Desa Sengon merupakan salah satu desa yang berada di Kabupaten Brebes. Masyarakat Desa Sengon rata - rata berpendidikan rendah dan pengetahuan mengenai makanan sehat sangatlah kurang. Kabupaten Brebes merupakan kabupaten/kota di jawa tengah yang memiliki angka jumlah gizi buruk tertinggi yaitu mencapai 219 kasus tahun 2019 (Dinkes Provinsi Jateng, 2019). Tidak hanya kasus gizi buruk, Kabupaten Brebes masuk dalam sepuluh besar kabupaten prioritas penanggulangan stunting dari 100 kabupaten di seluruh Indonesia yang akan diintervensi pada 2018. Data stunting tahun 2017 yang ada di Kabupaten Brebes 32,7 persen. Dari tingginya angka tersebut, Kabupaten Brebes masuk dalam sepuluh besar kabupaten prioritas penanggulangan stunting dari 100 kabupaten di seluruh Indonesia yang akan diintervensi pada 2018. Salah satu faktor yang berhubungan dengan stunting adalah pengetahuan orang tua mengenai gizi, menurut Pormes (2014) menyatakan bahwa ada hubungan antara pengetahuan orang tua mengenai gizi dengan stunting pada anak usia 4-5 tahun di TK Malaekat Pelindung Manado. Pola makan yang tidak tepat dan tidak seimbang juga merupakan salah satu faktor penyebab terjadinya stunting (Aramico, 2016).

Berdasarkan gambaran permasalahan yang telah dijabarkan maka dapat ditarik kesimpulan bahwa salah satu penyebab permasalahan gizi yang ada di Kabupaten Brebes terutama desa sengon disebabkan karena ketidaktauan masyarakat mengenai gizi seimbang. Permasalah tersebut yang melatarbelakangi dilakukannya penyuluhan mengenai "Peningkatan Pengetahuan Ibu Mengenai Gizi Seimbang dalam Pemenuhan Gizi Keluarga” pada ibu ibu rumah tangga di Desa Sengon.

\section{METODE}

Penyuluhan dalam rangka peningkatan pengetahuan ibu mengenai gizi seimbang dalam pemenuhan gizi keluarga dilakukan untuk mengatasi permasalahan mengenai masalah gizi di desa sengon. PkM dilakukan di Rumah Ketua RT 001 RW 003 Desa Sengon Kecamatan Ketanggungan Kabupaten Brebes pada bulan Juli 2019. Pemilihan tempat kegiatan berdasarkan letak tempat yang strategis dan mudah dijangkau oleh Warga Desa Sengon.

Target atau sasaran PkM ini yaitu Ibu - Ibu Rumah Tangga yang ada di Desa Sengon. Pelaksanaan kegiatan PkM ini menggunakan metode ceramah dengan bantuan alat peraga berupa gambar dan replika buah dan sayur dengan tujuan untuk mempermudah pemahaman mengenai gizi seimbang, menurut Masrikhiyah (2019) metode ceramah dengan menggunakan alat bantu dapat meningkatkan pengetahuan mengenai natural science pada siswa MI Ikhsaniyah Kupu dan menurut Warman (2019) penggunaan alat bantu berupa buku dapat meningkatkan kemampuan anak panti asuhan dalam berbahasa inggris.

Pelaksanaan kgiatan ini dibagi menjadi 3 tahapan yaitu tahapan persiapan, tahapan pelaksanaan kegiatan dan tahapan pelaksanaan wawancara setelah pelaksanaan kegiatan. 
Tahap I : Persiapan

Pada tahap ini meliputi mempersiapkan peralatan yang digunakan untuk menunjang penyuluhan meliputi alat bantu berupa gambar dan replika bahan makanan; kuesioner untuk wawancara; alat perekam dan alat tulis.

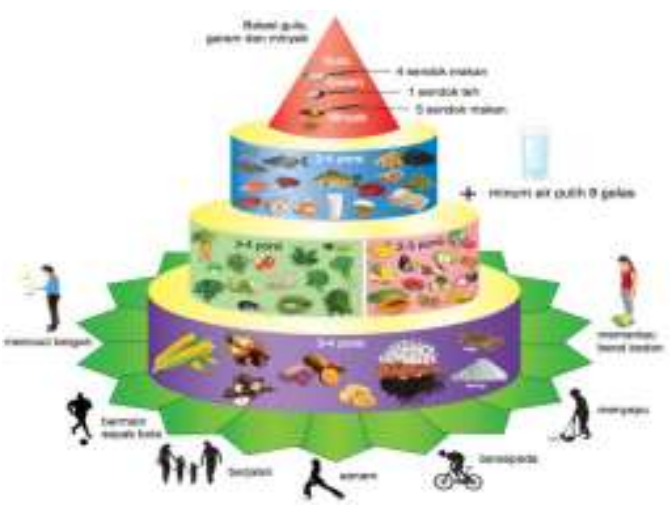

Gambar 1. Tumpeng Gizi Seimbang

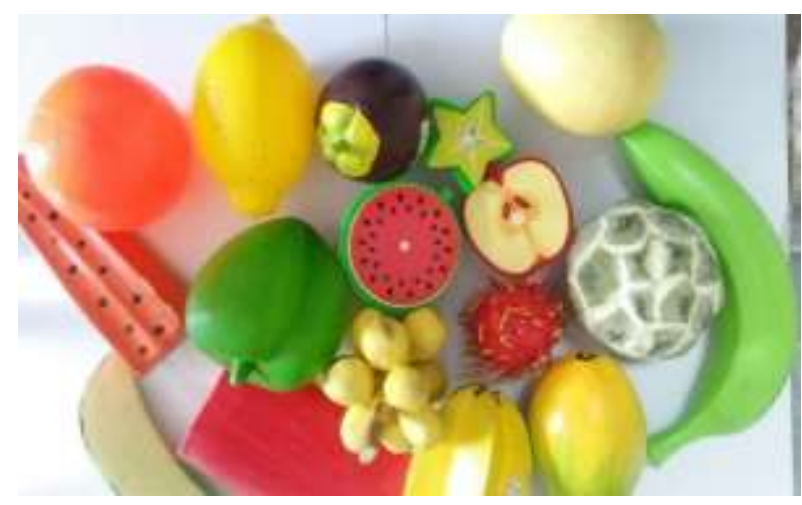

Gambar 2. Replika Buah - buahan

Tahap II: pelaksanaan kegiatan.

Pelaksanaan kegiatan meliputi ceramah dengan bantuan gambar dan replika bahan makanan. Materi ceramah kegiatan penyuluhan meliputi pola menu seimbang dan PUGS (Pedoman Umum Gizi Seimbang). Pelaksanaan Kegiatan dimualai dengan wawancara mengenai gizi seimbang yang kemudian dilanjutkan dengan ceramah dengan bantuan gambar dan replika dan yang terakhir diskusi. Wawancara dilakukan dengan tujuan mengetahui seberapa paham dan seberapa jauh pengetahuan ibu - ibu mengenai gizi seimbang sebelum dilakukan ceramah dan diskusi mengenai gizi seimbang.

Tahap III: pelaksanaan wawancara setelah pelaksanaan kegiatan

Wawancara dilakukan seminggu setelah dilaksanakan kegiatan kepada ibu -ibu yang telah mengikuti kegiatan PkM di Desa Sengon. Tujuan dilakukan wawancara, yakni untuk mengetahui pengaruh pelaksanaan kegiatan penyuluhan mengenai "Peningkatan Pengetahuan Ibu Mengenai Gizi Seimbang dalam Pemenuhan Gizi Keluarga" di Desa Sengon.

\section{HASIL DAN PEMBAHASAN}

Kegiatan PkM ini dilaksanakan menggunakan metode ceramah dengan bantuan gambar dan replika bahan bahan makanan. Pemilihan metode ini dipilih karena sebagian besar ibu - ibu yang mengikuti kegiatan PkM ini memiliki pendidikan rendah dan tidak dapat membaca dan menulis, sehingga metode ini cukup efektif digunakan dalam kegiatan peningkatan pengetahuan ibu mengenai gizi seimbang. Hal tersebut terlihat dalam proses kegiatan dimana ibu-ibu dalam mengikuti kegiatan tersebut sangat antusias, dapat dilihat dari adanya tanya jawab antara pemateri dengan ibu - ibu yang mengikuti kegiatan PkM. 


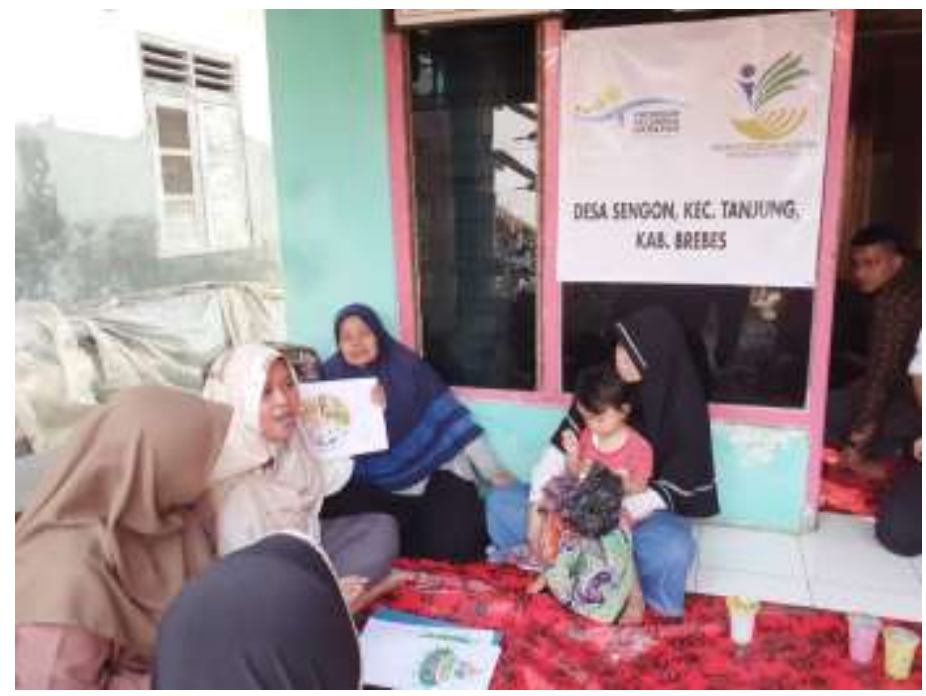

Gambar 3. Ceramah menggunakan alat bantu gambar

Seminggu setelah kegitan kemudian kami melakukan wawancara. Tujuan dilakukan wawancara adalah untuk melihat apakah ada peningkatan atau tidak setelah dilakukan kegiatan PkM. Wawancara dilakukan kepada ibu ibu yang telah mengikuti kegiatan PkM. Terdapat peningkatan pengetahuan ibu mengenai gizi seimbang yang dapat dilihat pada grafik gambar 3 .

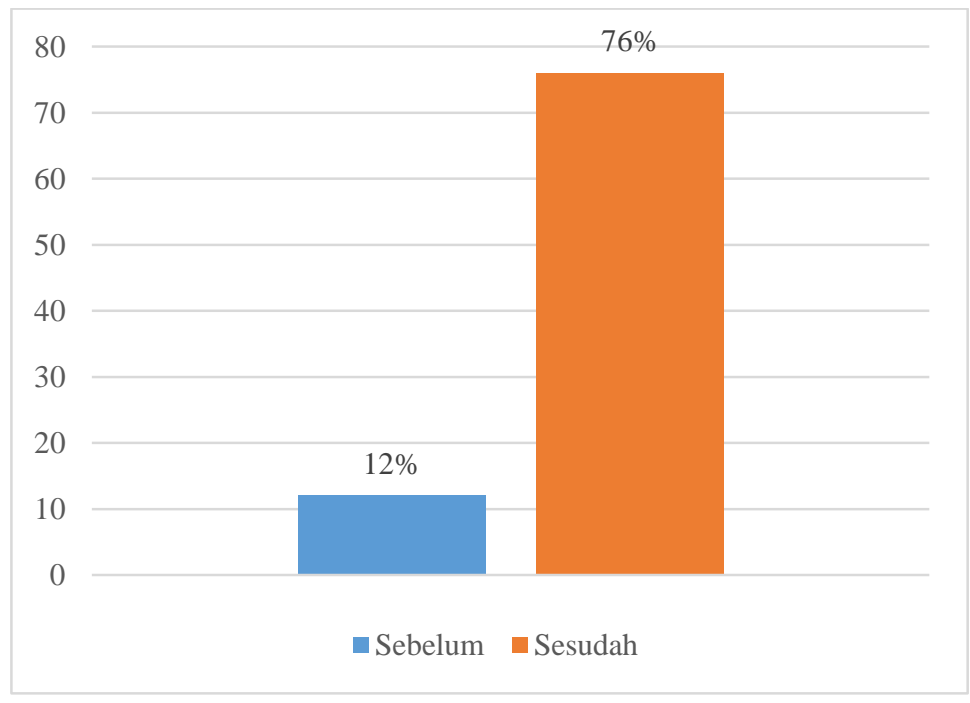

Gambar 3. Hasil Wawancara mengenai Pemahaman Ibu - Ibu Desa Sengon mengenai gizi seimbang sebelum dan sesudah kegiatan PkM

Gambar 3 menunjukkan mengenai pemahaman ibu - ibu Desa Sengon mengenai gizi seimbang sebelum dan sesudah dilakukan kegiatan PkM. Terdapat peningkatan yang signifikan sebelum dan sesudah dilakukan kegiatan PkM. Pada observasi awal hanya terdapat $12 \%$ ibu ibu yang mengetahu dan memahami gizi seimbang, setelah kegiatan PkM diadakan terjadi peningkatan yang signifikan yaitu menjai $76 \%$ dari total ibu - ibu yang mengikuti kegiatan. Sebelum diadakan kegiatan PkM, Ibu - Ibu sebagian besar tidak mengetahui mengenai gizi seimbang mereka lebih tahu mengenai 4 sehat 5 sempurna. Hal tersebut terlihat ketika sesi wawancara sebelum dilakukan kegiatan PkM mereka berpendapat bahwa makanan yang sehat itu yang penting ada susunya karena menurut mereka kalau ada susunya berarti sempurna seperti 4 sehat 5 sempurna tanpa diukur porsi dan tanpa aktivitas fisik. Ada juga yang berpendapat bahwa makanan yang sehat itu makanan yang mahal seperti pizza, burger dan fried 
chicken. Berikut contoh jawaban wawancara ketika ditanyakan "Apakah ibu mengetahui mengenai gizi seimbang?".

"Eenyong ora ngeri, nyong ngertine 4 sehat 5 sempurna, pokoke tah kalau mangan ana sega, sayur, lauk pauk ya wis sehat lan luwih sempuna ari ana susune (saya tidak tau mengenai gizi seimbang, saya tahunya 4 sehat 5 sempurna, yang penting makan kalau ada nasi, sayur, lauk pauk itu sudah sehat dan lebih sempurna kalau ada susunya)"

"Enyong ora paham, apa maksude panganan sing sehat. Ari panganan sing sehat ya sing larang larang oh kaya sing neng tv kaya pizza, burger toli ayam goreng (Saya tidak paham, apa kamsudnya makanan yang sehat. Kalau makanan yang sehat ya pokoknya makanan yang mahal seperti yang ada di TV contohnya pizza, burger dan fried chicken)"

Kegiatan PkM yang dilakukan memberikan efek yang bagus terhadap pengetahuan ibu ibu di Desa Sengon dimana terdapat peningkatan pengetahuan gizi seimbang dari $12 \%$ meningkat jadi $76 \%$ dari total ibu - ibu yang mengikuti kegiatan PkM. Peningkatan tersebut terlihat ketika seminggu setelah pelaksanaan kegiatan PkM dimana diadakan wawancara yaitu kepada ibu -ibu yang telah mengikuti kegiatan PkM dengan pertanyaan yang sama seperti pertanyaan sebelum dilakukan kegiatan PkM yaitu "Apakah ibu mengetahui mengenai gizi seimbang?". Berikut contoh jawaban salah satu narasumber.

"Gizi seimbang kuwe kaya 4 sehat 5 sempurna Cuma ana proporsine terus ana gerake (Gizi seimbang itu seperti 4 sehat 5 sempurna tetapi kalau gizi seimbang itu ada proporsinya dan juga ada aktivitas fisiknya)"

"Gizi seimbang kuwe panganane kudu beraneka ragam terus ana proporsine misale karbohidrat kuwe setengah sing kebutuhan energine, ora mung segane akeh nemen tapi lauke secuil nemen kudu seimbang ( Gizi seimbang yaitu makanan yang dimakan harus beraneka ragam kemudian harus ada proporsinya contohnya karbohidrat itu proporsinya setengah dari kebutuhan energi yang dibutuhkan oleh tubuh, tidak hanya nasinya yang banyak tapi lauk pauknya sedikit harus seimbang."

\section{KESIMPULAN}

Terdapat peningkatan pengetahuan yang signifikan mengenai gizi seimbang setelah diadakan kegiatan PkM mengenai upaya peningkatan pengetahuan ibu mengenai gizi seimbang di Desa Sengon dari 12\% menjadi 76\% total ibu yang mengikuti kegiatan PkM tersebut.

\section{UCAPAN TERIMA KASIH}

Terimakasih kepada kepala Desa Sengon dan Pendamping PKH yang berkenan membantu dalam kegiatan $\mathrm{PkM}$, sera rekan rekan sejawat yang telah membantu dalam pelaksanaan kegiatan PkM.

\section{DAFTAR PUSTAKA}

Adityanti, M.A., Mustikaningsih, D. dan Syamsiatu, N.H. (2015). Faktor-faktor yang mempengaruhi kejadian obesitas pada remaja. Jurnal Gizi Klinik Indonesia. 11(4). 179-190.

Aramico, B., Sudargo, T., \& Susilo, J. (2016). Hubungan sosial ekonomi, pola asuh, pola makan dengan stunting pada siswa sekolah dasar di Kecamatan Lut Tawar, Kabupaten Aceh Tengah. Jurnal Gizi dan Dietetik Indonesia (Indonesian Journal of Nutrition and Dietetics), 1(3), 121-130.

Dinas Kesehatan Provinsi Jawa Tengah. 2019. Buku saku kesehatan triwulan 3 tahun 2019. http://dinkesjatengprov.go.id/v2018/dokumen/bukusakutw32019/index.html\#p=1. Diakses pada Rabu, 11 Februari 2019 pukul 10.14 WIB. 
Irnani, H. Dan Sinaga, T. (2017). Pengaruh Pendidikan Gizi Terhadap Pengetahuan, Praktik Gizi Seimbang Dan Status Gizi Pada Anak Sekolah Dasar. Jurnal Gizi Indonesia (The Indonesian Journal of Nutrition). 6 (1). 58-64.

Masrikhiyah, R., 2019. Peningkatan Mutu Pengetahuan Siswa Mengenai Natural Science Di Mi Ikhsaniyah Kupu: Pengenalan Dan Praktik Penggunaan Mikroskop. Randang Tana-Jurnal Pengabdian Masyarakat, 2(1), 39-45.

Octaviani, I.A. dan Margawati, A. (2012). Hubungan Pengetahuan Dan Perilaku Ibu Buruh Pabrik Tentang Kadarzi (Keluarga Sadar Gizi) Dengan Status Gizi Anak Balita (Studi Di Kelurahan Pagersari, Ungaran). Journal of nutrition Collage. 1(1).46-54.

Pormes, W. E., Rompas, S., \& Ismanto, A. Y. (2014). Hubungan pengetahuan orang tua tentang gizi dengan stunting pada anak usia 4-5 tahun di TK Malaekat Pelindung Manado. Jurnal Keperawatan, 2(2).

Riset Kesehatan Dasar. (2018). Proporsi Gizi Kurang Dan Gemuk Pada Balita. Jakarta: Badan Penelitian dan Pengembangan Kesehatan, Departemen Kesehatan, Republik Indonesia.

Suparmi, Syafrani, \& Sumarto. (2019). Pelatihan Teknologi Fortifikasi Daging Ikan Sebagai Sumber Protein Nugget Ubi Kayu Di Desa Tambusai Batang Dui. Dinamisia: Jurnal Pengabdian Kepada Masyarakat, 3(1), 181-187.

Warman, J. S., Mardian, V., Suryani, L., \& Irwan, F. R. F. I., 2019. Program Pelatihan Penigkatan Kemampuan Bahasa Inggris Anak-Anak Panti Asuhan Melalui Pemberdayaan Mahasiswa. Dinamisia: Jurnal Pengabdian Kepada Masyarakat, 3(2), 280-285. 